\title{
Lipooxygenase Inhibitor
}

National Cancer Institute

\section{Source}

National Cancer Institute. Lipooxygenase Inhibitor. NCI Thesaurus. Code C1322.

Any substance that inhibits lipooxygenase, an enzyme that catalyses the dioxygenation

of polyunsaturated fatty acids in lipids. Lipooxygenase is involved in the metabolism of eicosanoids (such as prostaglandins and leukotrienes) and its inhibition can suppress hypersensitivity reactions. 